\title{
Pengaruh Penerapan Pembelajaran Kooperatif Tipe NHT (Numberead Head Together) terhadap Aktivitas dan Prestasi Belajar Kimia Pokok Bahasan Konsep Hidrokarbon
}

\author{
Ammi Latifatunnisak \\ Ma Nw Boro' Tumbuh, Lombok, Indonesia \\ *Coresponding Author: ammilatifatunnisak@gmail.com
}

\begin{abstract}
Abstrak: Salah satu model pembelajaran ynag dapat mengajak siswa berfikir dan menyebabkan siswa aktif yaitu pembelajaran tipe NHT (Numberead Head Together). Penelitian ini bertujuan untuk mengetahui pengaruh model pembelajaran tipe NHT terhadap aktivitas siswa dan ketuntasan belajar kimia pada pokok bahasan konsep hidrokarbon pada siswa kelas X MA NW Boro' Tumbuh tahun pelajaran 2009/2010. Populasi dalam penelitian ini adalah seluruh siswa kelas X MA NW Boro' Tumbuh tahun pelajaran 2009/2010 ynag berjumlah 64 orang siswa dalam dua kelas. Sampel dalam penelitian ini diambil semua karena terdiri dari dua kelas yaitu satu kelas untuk kelas kontrol dan satu kelas untuk kelas eksperimen. Dalam penelitian ini diperoleh nilai rata-rata kelas kontrol adalah 66.8, sedangkan nilai rata-rata kelas eksperimen adalah 76.7. Untuk analisis data dalam penelitian ini digunakan uji t polled varians dengn taraf signifikan $5 \%$ dan diperoleh hasil bahwa $t_{\text {hitung }}$ adalah sebesar 2.86 dan tabel sebesar 1.998. Kesimpulan penelitian ini adalah model pembelajaran tipe NHT (Numberead Head Togheter) berpengaruh terhadap ketuntasan belajar kimia pada pokok bahasan konsep hidrokarbon siswa kelas X MA NW Boro' Tumbuh tahun pelajaran 2009/2010, tetapi tidak berpengaruh terhadap aktivitas siswa.
\end{abstract}

Kata Kunci: Pembelajaran Kooperatif Tipe NHT; Aktivitas dan Prestasi Belajar; Hidrokarbon

\section{PENDAHULUAN}

Belajar adalah proses memanusiakan manusia dimana hanya melalui belajarlah manusia menemukan dirinya dalam relasinya dengn sesama, lingkungan dan Sang Pencipta. Melalui belajar manusia mengaktualisasikan diri dan lingkungannya sedemikian rupa, sehingga kualitas dan kehidupannya menjadi lebih baik. Untuk itu dalam rangka mencerdaskan kehidupan bangsa, seperti ynag termaktub dalam pembukaan UUD 1945 dan untuk memenuhi kebutuhan pendidikan ynag semakin meningkat di kalangan masyarakat Indonesia dewasa ini, maka sangat diperlukan tenaga pendidik (Guru) ynag baik dari segi kualitas maupun kuantitas. Namun masalah berhasilnya pendidikan juga harus ditunjang oleh pribadi siswa seperti minat, motivasi, intelegensi, kemauan atau faktor internal maupun eksternal dari siswa dalam hal belajar (Anonim, 2004).

Guru adalah unsur manusia dalam pendidikan, unsur manusia lainnya yaitu anak didik. Guru dan anak didik barada dalam suatu relasi kejiwaan, keduanya barada dalam proses edukatif dengn tugas dan peranan ynag berbeda, guru mengajar dan mendidik, sedangkan anak didik menerima bahan pelajaran dari guru di kelas. Guru dan anak didik berada dalam koridor kebaikan. Oleh karena itu, walaupun mereka berlainan secara fisik dan mental, tetapi mereka tetap seiring dan bertujuan untuk mencapai kebaikan akhlak moral, hukum sosial, budaya dan sebagainya. Guru menempati posisi dan memegang peranan ynag penting dalam proses belajar mengajar di kelas. Gurulah ynag pertama-tama harus pandai menggunakan pendekatan secara arif dan bijaksana dan mempu meningkatkan minat dan perestasi belajar anak didiknya (Djamarah,1997 ). 
Latar belakang siswa dalam berpikir mempunyai tingkat ynag berbeda-beda. Ada kelompok siswa ynag pintar (cepat menyerap materi pelajaran), kelompok siswa ynag sedang (tidak cepat tapi juga tidak lambat menerima materi pelajaran), dan ada kelompok siswa ynag lambat menerima materi pelajaran. Untuk menyeimbangkan daya serap siswa perlu dilakukan inovasi pembelajaran dengn cara menerapkan strategi baru ynag lebih aktif supaya mampu meningkatkan kemampuan siswa dalam memahami konsep kimia. Strategi ynag diperlukan adalah penggunaan metode pembelajaran ynag tidak mengharuskan siswa hanya mendengarkan, mencatat dan menghafal materi ynag diajarkan, tetapi juga mendorong siswa untuk berpikir, bekerja, dan beraktivitas selama proses pembelajaran sehingga membawa mereka ke suasana ynag menyenangkan.

Adapun model pembelajaran ynag mampu mengajak siswa bekerja secara bersama-sama dan menyebabkan siswa aktif adalah model pembelajaran kooperatif. Di sisi lain Ibrahim dkk (2000) menyebutkan pembelajaran kooperatif mencerminkan pandangan bahwa manusia belajar dari pengalaman mereka dan partsipasi aktif dalam kelompok kecil, membantu siswa belajar keterampilan sosial ynag penting sementara itu secara bersamaan mengembangkan sikap demokratif dan keterampilan berpikiran logis.NHT merupakan satu tipe pembelajaran kooperatif ynag melibatkan banyak siswa dalam menelaah materi. Dalam pembelajaran kooperatif NHT siswa dibagi beberapa kelompok ynag beranggotakan 3-5 dan setiap anggota kelompok diberi nomor $1-5$

Berdasarkan hasil observasi awal dengn guru mata pelajaran kimia kelas X MA NW Boro' Tumbuh Lombok Timur, selama ini guru masih menggunakan metode ceramah dan masih belum menggunakan metode ynag baru. Penggunaan metode ceramah ynag aktif dalam proses pembelajaran hanyalah siswa dan daya serapnya lebih cepat, sedangkan siswa ynag daya serapnya kurang menjadi pasif. Hal ini dapat ditunjukkan dari persentase ketuntasan belajar siswa kelas X MA NW Boro' Tumbuh Tahun Ajaran 2008/2009 pada pokok bahasan hidrokarbon,seperti pada tabel berikut:

Tabel 1. Nilai rata-rata ulangan harian pokok bahasan hidrokarbon tahun pelajaran $2008 / 2009$

\begin{tabular}{|c|c|c|c|c|}
\hline Kelas & Jumlah siswa & Nilai rata-rata & Jumlah siswa tuntas & \% ketuntasan \\
\hline X.1 & 30 & 59.56 & 14 & $46.67 \%$ \\
\hline X.2 & 29 & 65.06 & 14 & $48.27 \%$ \\
\hline
\end{tabular}

Berdasarkan latar belakang di atas, maka perlu dilakukan penelitian ynag terkait dengn hal tersebut dengn judul "Pengaruh Penerapan Pembelajaran Kooperatif Tipe NHT (Numbered Head Together) Terhadap Aktivitas Siswa dan Prestasi belajar Kimia Pokok Bahasan Konsep Hidrokarbon Kelas X MA NW Boro' Tumbuh Tahun Ajaran 2009/2010 “

\section{KAJIAN TEORI}

\section{Model Pembelajaran Koperatif}

Pembelajaran kooperatif adalah konsep ynag lebih luas meliputi semua jenis kerja kelompok termasuk bentuk-bentuk ynag lebih dipimpin oleh guru atau diarahkan oleh guru. Secara umum pembelajaran kooperatif dianggap lebih diarahkan oleh guru, dimana guru menetapkan tugas dan per menyediakan 
bahatanyaan-pertanyaan sertan imformasi ynag dirancang untuk membantu peserta didik menyelesaikan masalah ynag dimaksud.

Pembelajaran kooperatif tidak sama dengn sekedar belajar kelompok. Ada unsur-unsur dasar pembelajaran kooperatif ynag membedakan dengn pembagian kelompok ynag dilakukan asal-asalan. Pelaksanaan prosedur model pembelajaran kooperatif dengn benar akan dapat menumbuhkan pembelajaran ynag bercirikan :

- Memudahkan siswa belajar, sesuatu ynag bermanfaat seperti fakta, keterampilan, nilai, konsep, dan bagaimana hidup serasi dengn sesama.

- Pengetahuan,nilai dan keterampilan diakui oleh mereka ynag berkompenten menilai (Suprijono,2009)

\section{Pembelajaran Kooperatif Tipe Numbered Head Together (NHT)}

Numbered Head Togethers adalah suatu pendekatan ynag dikembangkan oleh Spencer Kagen (1993) dalam Ibrahim (2000) untuk melibatkan lebih banyak siswa dalam menelaah materi ynag tercakup dalam suatu pelajaran dalam mengecek pemahaman terhadap isi pelajaran tersebut. Selanjutnya kepada seluruh kelas, guru menggunakan struktur 4 langkah sebagai berikut:

\section{Langkah 1. Penomeran}

Guru membagi siswa ke dalam kelompok beranggotakan 3-5 orang dan kepada setiap kelompok diberi nomor 1-5.

\section{Langkah 2. Mengajukan pertanyaan}

Guru mengajukan sebuah pertanyaan kepada siswa. Pertanyaan dapat bervariasi, pertanyaan dapat amat spesifik dan dalam bentuk kalimat tanya atau arahan

\section{Langkah 3. Berpikir bersama}

Siswa menyatukan pendapatnya terhadap jawaban pertanyaan itu dan meyakinkan tiap anggota kelompok dalam timnya mengetahui jawaban itu.

\section{Langkah 4. Menjawab}

Guru memanggil satu nomor tertentu,kemudian siswa ynag nomornya sesuai mengacungkan tangan dan menjawab pertanyaan untuk seluruh kelas.

\section{Aktivitas siswa dalam pembelajaran}

Aktivitas belajar menurut (Hamalik,2001) adalah suatu proses atau kegiatan ynag dilakukan untuk mencapai pengetahuan,pemahaman,dan aspek-aspek tingkah laku lainya,serta mengembangkan keterampilan ynag bermakna untuk hidup di masyarakat.

Penggunaan asas aktivitas besar nilainya bagi pengajaran para siswa,oleh karena : (Hamalik,2001)

- Para siswa mencari pengalaman sendiri dan langsung mengalami sendiri.

- Berbuat sendiri akan mengembangkan seluruh aspek pribadi siswa.

- Memupuk kerja sama ynag harmonis di kalangan siswa.

- Para siswa bekerja menurut minat dan kemampuan sendiri.

- Memupuk disiplin kelas secara wajar dan suasana belajar menjadi demokratis.

- Mempererat hubungan sekolah dan masyarakat,dan hubungan antar orang tua dan guru.

- Pengajaran diselenggarakan secara realistis dan konkret sehingga mengembangkan pemahaman dan berpikir kritis serta menghindarkan verbalisme. 
- Pengajaran disekolah semakin hidup sebagaimana aktivitas dalam kehidupan di masyarakat.

Telah diketahui bahwa aktivitas belajar tidak semuanya sama. Hal ini dipengaruhi oleh penggunaan metode dan pendekatan belajar mengajar. Ketidaksamaan aktivitas siswa itu melahirkan kadar aktivitas belajar ynag bergerak dari aktivitas belajar rendah sampai aktivitas belajar ynag tinggi.

\section{Prestasi belajar}

Adapun faktor-faktor ynag mempengaruhi prestasi belajar siswa terbagi menjadi faktor internal dan faktor eksternal. Faktor internal meliputi kondisi jasmani dan kondisi rohani sedangkan faktor eksternal meliputi faktor lingkungan sosial, nonsosial dan faktor pendekatan belajar (Slameto, 2003).

\section{METODE PENELITIAN}

\section{Rancangan Penelitian}

Jenis penelitian ynag digunakan dalam penelitian ini adalah jenis penelitian eksperimental karena digunakan untuk mencari pengaruh perlakuan tertentu terhadap ynag lain dalam kondisi ynag terkendalikan.

Rancangan ynag digunakan dalam penelitian ini adalah posttest-only control group design. Dalam design ini terdapat dua kelompok ynag masing-masing dipilih secara random. Kelompok disebut kelompok eksperimen ynag diberi perlakuan menggunakan metode pembelajaran kooperatif tipe NHT dan kelompok kedua disebut kelompok kontrol ynag diberi perlakuan menggunakan metode ceramah. Hasil pembelajaran dari kedua kelompok tersebut dianalisis dan diuji statistik dengn menggunakan uji t.

\section{Populasi dan Sampel Penelitian}

Langkah-langkah penelitian ynag dilakukan dalam pelaksanaan penelitian meliputi :

\section{Populasi}

Populasi adalah keseluruhan subyek penelitian (Arikunto, 2006 ). Populasi dalam penelitian ini adalah seluruh siswa kelas X MA NW Boro' Tumbuh Tahun Pelajaran 2009/2010 ynag tersebar dalam 2 kelas dengn jumlah seluruh populasi 64 seperti ynag tercantum pada tabel di bawah ini :

Tabel 2. Populasi penelitian

\begin{tabular}{|l|c|c|}
\hline No & Kelas & Jumlah \\
\hline 1 & X.1 & 31 \\
\hline 2 & X.2 & 33 \\
\hline & Jumlah & 64 \\
\hline
\end{tabular}

\section{Sampel}

Sampel adalah sebagian dari populasi ynag diteliti (Arikunto, 2006). Selanjutnya tentang teknik pengambilan sampel apabila subyeknya atau populasi kurang dari 100 , lebih baik diambil semuanya sehingga penelitiannya merupakan penelitian populasi. Penentuan sampel dilakukan melalui purposive sample yaitu dengn cara mengambil subjek bukan didasarkan atas random atau daerah tetapi 
didasarkan atas adanya tujuan tertentu. Dilihat dari nilai rata-rata ulangan harian pada pokok bahasan sebelumnya yaitu reaksi redoks kelas $\mathrm{X}$ tahun pelajaran 2009/2010 maka ynag menjadi kelas kontrol adalah kelas X.1 ynag memiliki nilai rata-rata lebih rendah sedangkan ynag menjadi kelas eksperimen adalah kelas X.2 ynag memiliki nilai rata-rata lebih tinggi.

\section{Instrumen Penelitian}

Instrumen penelitian adalah alat atau fasilitas ynag digunakan oleh peneliti dalam mengumpulkan data agar pekerjaanya lebih mudah dan hasilnya lebih baik dalam arti lebih cermat,lengkap dan sistimatis sehingga lebih mudah diolah (Arikunto, 2006)

Instrumen ynag digunakan dalam penelitian ini adalah:

1. Lembar Observasi

Lembar observasi digunakan untuk mengetahui aktivitas siswa dan respon siswa terhadap metode ynag digunakan

2. Tes hasil belajar

Tes hasi belajar berupa soal-soal tertulis ynag bersifat obyektif ynag digunakan untuk mendapatkan data tentang prestasi belajar siswa ynag berjumlah 35 soal.

Sebelum tes hasil belajar tersebut digunakan terlebih dahulu dilakukan analisis instrumen. Analisis instrument digunakan untuk mengetahui kualitas butir soal tes ynag dilakukan melalui uji coba untuk mencari validitas butir soal dan reabilitas soal. 1. Validitas Butir Soal

Validitas adalah ukuran ynag menunjukkan keabsahan atau kevaliditan sebuah instrumen (Arikunto, 2006). Sebuah item dikatakan valid jika skor pada item tersebut mempunyai kesejajaran dengn slor soal. Untuk mengetahui validitas item digunakan rumus korelasi prodavt moment, dimana instrument dikatakan valid jika $\mathrm{r}$ hitung $>\mathrm{r}$ table dan instrumen dikatakan tidak valid jika $r$ hitung $\leq r$ table (Sugiyono, 2005)

2. Reliabilitas soal

Reabilitas soal artinya dapat dipercaya. Reabilitas untuk tes obyektif dapat dicari dengn menggunakan rumus KR-20 (Arikunto, 2006).

\section{Tehnik Pengumpulan Data}

Tehnik pengumpulan data ynag digunakan dalam penelitian ini adalah:

\section{Observasi}

Observasi merupakan langkah untuk mengamati aktivitas selama proses pembelajaran berlangsung melalui lembar observasi

2. Tes hasil belajar

Tes hasil belajar merupakan tes ynag digunakan untuk mengetahui hasil akhir dari proses pembelajaran berdasarkan indikator.

\section{Tehnik Analisa Data}

1. Data Analisis Aktivitas

Untuk menghitung skor setiap aktivitas belajar siswa dan aktivitas guru digunakan rumus : 


$$
A=\frac{\sum x}{i}
$$

Keterangan :

$$
\begin{aligned}
& A=\text { Rata-rata skor aktivitas guru } \\
& \sum \mathrm{x}=\text { Jumlah skor aktivitas guru } \\
& \mathrm{N}=\text { Banyak skor seluruh item }
\end{aligned}
$$

2. Data hasil belajar

a Menentukan nilai rata-rata

Untuk mengetahui nilai rata-rata kelas digunakan rumus sebagai berikut:

$$
\begin{aligned}
& \quad R=\frac{\sum x}{N} \\
& \text { Keterangan : } \\
& \mathrm{R}=\text { Nilai rata-rata } \\
& \mathrm{N}=\text { Jumlah seluruh siswa ynag mengikuti tes } \\
& =\text { Jumlah nilai ynag diperoleh }
\end{aligned}
$$

b. Ketuntasan individu (hasil evaluasi belajar)

Hasil belajar siswa dapat ditentukan dengn berpatokan pada kriteria ketuntasan ynag telah ditetapkan. Skor ynag diperoleh siswa melalui Tes Hasil Belajar (THB) akan digunakan untuk menentukan ketuntasan individu terhadap indikator ynag telah ditetapkan. Ketuntasan individual atau ketuntasan per siswa ditentukan dengn rumus berikut (Azhar, 1993).

\section{Uji Beda ( uji t )}

Uji - $\mathrm{t}$ digunakan untuk mengetahui prestasi belajar perbedaan antara kelas kontrol dan kelas eksperimen. Sebelum uji t dilakukan uji homogenitas untuk menguji varians tersebut homogen atau tidak. Setelah diketahui varians homogen atau tidak selanjutnya dilakukan uji t. Rumus Uji t ynag digunakan tergantung dari homogen tidaknya varians data. Bila varians homogen dapat digunakan rumus pooled svarians. Kemudian t hitung dibandingkan dengn $t$ tabel , apabila $t$ hitung lebih kecil dari $\mathrm{t}$ tabel ( $\mathrm{t}$ hitung $\leq \mathrm{t}$ tabel ),maka Ho ditolak dan Ha diterima (Sugioyono, 2005).

\section{HASIL DAN PEMBAHASAN}

Pelaksanaan penelitian ini dilakukan pada dua kelas yaitu kelas eksperimen ( X.2 ) dan kelas kontrol ( X.1 ). Kegiatan belajar mengajar dilakukan dalam tiga kali pertemuan pada masing-masing kelas. Selanjutnya diadakan evaluasi pada setiap kelas setelah seluruh proses pembelajaran selesai dengn menggunakan tes hasil belajar dalm bentuk tes evaluasi pada setiap kelas berupa tes pilihan ganda.

Pengumpulan data pada penelitian ini dilaksanakan dalam tahapan yaitu melakukan uji validitas dan reliabilitas instrumen dari siswa kelas eksperimen dan kelas kontrol ynag diikuti oleh 64 siswa setelah proses pembelajaran pada pokok bahasan konsep hidrokarbon selesai.

1. Uji Coba Instrumen
a. Uji Validitas 
Uji validitas soal-soal tes materi pokok hidrokarbon,dari 35 soal ynag diujikan ,diperoleh 18 soal ynag valid dengn ketentuan $r_{\text {hitung }}>r_{\text {tabel }}(0.246)$ dan 17 butir soal ynag tidak valid dengn ketentuan $r_{\text {hitung }} \leq r_{\text {tabel }}$.

b. Uji Realiabilitas

Dari 18 butir soal pokok materi hidrokarbon ynag valid tersebut dilakukan uji reliabilitas dan didapat $\mathrm{r}_{11}$ ( $\mathrm{r}$-hitung ) sebesar 0.78. harga ini lebih besar dibandingkan dengn harga $r$ - tabel pada taraf signifikan $5 \%$ sebesar 0.246. Harga $r$ hitung ynag diperoleh tergolong dalam kategori tinggi

2. Data Hasil Belajar Siswa

Data hasil penelitian berupa hasil belajar siswa diperoleh dari hasil tes pada pokok materi hidrokarbon dengn jumlah sampel ynag mengikuti tes pada pokok materi hidrokarbon adalah 64 orang ynag terdiri dari 33 orang siswa dari kelas eksperimen (X.2) dan 31 orang dari kelas kontrol (X.1). Adapun data hasil belajar dapat dilihat pada tabel dibawah ini :

Tabel 3. Data hasil belajar

\begin{tabular}{|c|c|c|c|}
\hline No & Nilai & Kontrol & Eksperimen \\
\hline 1 & Nilai tertinggi & 94.4 & 94.4 \\
\hline 2 & Nilai terendah & 22.2 & 27.7 \\
\hline 3 & Rata-rata & 66.8 & 76.7 \\
\hline 4 & Ketuntasan & $64.51 \%$ & $84.84 \%$ \\
\hline
\end{tabular}

Berdasarkan hasil perhitungan menggunakan uji homogenitas varians, diketahui bahwa varians untuk kelas kontrol sebesar 395.87 dan varians untuk kelas eksperimen sebesar 311.44 diperoleh harga F-hitung sebesar 1.27 dengn F-tabel sebesar 1.82 dari dk penyebut $33(33-1=32)$ dan dk pembilang $31(31-1=30)$. Jadi dari hasil perhitungan diperoleh F-hitung $\leq$ F-tabel,sehingga kedua kelas sampel bersifat homogen dan uji-t ynag digunakan adalah uji-t polled varians pada taraf signifikan $5 \%$.

Berdasarkan hasil perhitungan uji-t polled varians diperoleh t hitung sebesar 2.22 dan harga t-tabel untuk taraf signifikan $5 \%$ dengn derajat kebebasan $(\mathrm{dk}) \mathrm{n}_{1}+$ $\mathrm{n}_{2}-2=33+31=64$ sebesar 1.998, sehingga diperoleh $\mathrm{t}$-hitung $>\mathrm{t}$-tabel $(2.86>1.998)$. Dari Hasil perhitungan tersebut dapat dikatakan bahwa ada perbedaan ketuntasan belajar antara kelas kontrol dan kelas eksperimen pada pokok bahasan hidrokarbon. Sedangkan dilihat dari nilai rata-rata pada kelas kontrol sebesar 66.8 dan kelas eksperimen sebesar 76.7 dapat disimpulkan bahwa " ada pengaruh positif penerapan model pembelajaran kooperatif tipe NHT (Numberead Head Together) terhadap prestasi belajar kimia pokok bahasan hidrokarbon siswa kelas X MA NW Boro' Tumbuh tahun pelajaran 2009/2010.

3. Data Aktivitas Siswa

Hasil observasi diperoleh dari pengamatan ynag dilakukan oleh guru dengn mengisi lembar observasi ynag telah dipersiapkan oleh peneliti ynag bertujuan untuk merekam jalannya proses belajar mengajar. Observasi terhadap aktivitas siswa dilakukan dengn mengamati perilaku siswa pada saat diskusi dalam kelompoknya dan proses belajar mengajar. Semua aktivitas ynag nampak dicatat dalam lembar observasi sesuai dengn deskriptor ynag nampak 
Adapun hasil analisa data tersebut tertuang pada tabel :

Tabel 4. Data hasil analisis aktivitas siswa

\begin{tabular}{|c|c|c|c|c|c|}
\hline \multicolumn{4}{|c|}{ Kelas Eksperimen } & \multicolumn{2}{c|}{ Kelas Kontrol } \\
\hline No & Pertemuan & Skor Aktif & Keterangan & Skor aktif & Keterangan \\
\hline 1 & I & 2.4 & Aktif & 1.67 & Cukup aktif \\
\hline 2 & II & 3 & Aktif & 1.8 & Cukup aktif \\
\hline 3 & II & 3.6 & Sangat aktif & 2.5 & Aktif \\
\hline \multirow{2}{*}{} & Jumlah & 9 & & 5.97 & \\
\cline { 2 - 6 } & Rata-rata & 3 & Aktif & 1.99 & Cukup aktif \\
\hline
\end{tabular}

Berdasarkan tabel diatas diperoleh varians untuk kelas kontrol sebesar 0.993 sedangkan pada kelas eksperimen sebesar 0.36 dan diperoleh harga F-hitung 1.806 dengn F-tabel 3.35,jadi hasil perhtungan diperoleh F-hitung < F-tabel ( $1.086<$ 3.35) sehingga kedua kelas sampel bersifat homogen, Sedangkan untuk uji-t diperoleh t-hitung sebesar 2.34 dan harga t-tabel untuk taraf signifikan $5 \%$ dengn derajat kebebasan (dk) 3+3 -2 = 4 adalah 2.776 sehingga diperoleh t-hitung lebih kecil dari t-tabel $(2.34<2.776)$. Dari hasil perhitungan tersebut dapat disimpulkan bahwa tidak ada pengaruh penerapan model pembelajaran kooperatif tipe NHT terhadap aktivitas siswa pada kelas X MA NW Boro' Tumbuh tahun pelajaran 2009/2010 “

\section{Pembahasan}

Berdasarkan hasil uji statistik menunjukkan bahwa adanya pengaruh model pembelajaran kooperatif tipe NHT (Numbered Head Together) terhadap ketuntasan belajar kimia siswa kelas X.2 MA NW Boro' Tumbuh 2009/2010 pokok bahasan konsep hidrokarbon.

Jadi dari hasil penelitian di atas ynag diperoleh ternyata pembelajaran kooperatif tipe NHT ini dapat meningkatkan ketuntasan belajar. Kecenderungan peningkatan aktivitas belajar dan ketuntasan belajar siswa menunjukkan peningkatan ynag berarti setelah dilakukan perbaikan-perbaikan disamping hambatan-hambatan ynag sering terjadi dalam kegiatan belajar mengajar pada umumnya.

Berdasarkan hasil hasil homogenitas dan uji-t diatas dapat dikatakan bahwa penerapan model pembelajaran tipe NHT memberikan pengaruh terhadap aktivitas siswa dan ketuntasan belajar kimia pada kelas eksperimen. Hal ini juga dapat dilihat dari hasil pengamatan untuk kelas eksperimen ynag menggunakan model pembelajaran tipe NHT terlihat kerjasama dan interaksi siswa dalam kelompoknya masing-masing berlangsung dengn baik Tehnik pengelompokan diadakan secara heterogen sehingga dalam satu kelompok akan terjadi interaksi ynag baik, siswa ynag pandai dapat memberitahu temenya ynag kurang pandai.

Dalam pembelajaran ini masih ada beberapa siswa ynag belum tuntas belajar secara individual sehingga perlu mendapatkan perhatian dan penanggulangan khusus dari guru bidang studi ynag bersangkutan, dengn demikian pelaksanaan pembelajaran dengn metode kooperatif dan pendekatan ini dapat meningkatkan prestasi belajar siswa tetapi keterbatasan waktu untuk melanjutkan dengn tetap menggunakan pendekatan ini maka diharapkan pihak ynag bersangkutan memberikan secara kontinu mengenai dasar pembelajaran dengn pendekatan 
struktural dan mengadakan bimbingan khusus pada siswa ynag prestasinya masih rendah terutama ynag belum mencapai ketuntasan belajar secara individual.

Berdasarkan hasil penelitian dan analisis diatas maka dapat dijelaskan bahwa model pembelajaran tipe NHT ynag diterapkan pada mata pelajaran kimia khususnya pada pokok bahasan konsep hidrokarbon memberi pengaruh positif terhadap aktivitas dan ketuntasan belajar siswa kelas X MA NW Boro' Tumbuh Tahun Pelajaran 2009/2010. Diharapkan penerapan pembelajaran tipe NHT ini dapat meningkatkan kemampuan siswa dalam menyelesaikan soal-soal khususnya pada pelajaran kimia,sehingga siap menghadapi ulangan dan senang belajar kimia. Hal ini merupakan salah satu upaya guru untuk membantu siwa dalam memperoleh kesiapan belajar.

\section{KESIMPULAN}

Berdasarkan hasil penelitian dan pembahasan, maka dapat disimpulkan bahwa: 1) Tidak ada pengaruh penerapan model pembelajaran kooperatif tipe NHT (Numbered Head Together) terhadap aktivitas siswa kelas X MA NW Boro' Tumbuh Tahun Pelajaran 2009/2010"; 2) Ada pengaruh model pembelajaran kooperatif tipe NHT (Numberead Head Together) terhadap prestasi belajar pada pokok bahasan hidrokarbon siswa kelas X MA NW Boro’ Tumbuh Tahun Pelajaran 2009/2010.

Saran dan tindak lanjut dari penelitian ini adalah: 1) Diharapkan kepada guru untuk mencoba menerapkan model pembelajaran kooperatif tipe Numbered Head Together pada bidang ynag sama pokok bahasan ynag lain; 2) Diharapkan kepada guru senantiasa selalu mengawasi siswanya agar tidak banyak bermain-main pada waktu di kelas, karena kelas kooperatif sedikit ribut bila dibandingkan dengn kelas lain karena pada saat itu siswa melakukan diskusi; dan 3) Model pembelajaran tipe Numbered Head Together dapat dijadikan alternatif bagi guru dalam meningkatkan penguasaan konsep-konsep kimia siswa ynag pada akhirnya akan meningkpatkan hasil belajar siswa

\section{DAFTAR PUSTAKA}

Anonim, (2004). Model-Model Pembelajaran Sain.Jakarta : Depdiknas

Arikunto, (2002). Dasar-Dasar Evaluasi Pendidikan. Jakarta : Rineka Cipta

Arikunto, (2006). Prosedur Penelitian Suatu Pendekatan Praktek. Jakarta : Rineka Cipta

Dimyanti, Mudjiono. (2006). Belajar Dan Pembelajaran . Jakarta : Rineka Cipta

Djamarah. (1994). Prestasi Belajar Dan Kompetensi Guru. Usaha Nasional: Surabaya

Djamarah, (1997). Guru Dan Anak Didik. Jakarta : Rineka Cipta

Hamalik, (2001). Proses Belajar Mengajar. Jakarta : Bumi Aksara

Ibrahim, M. dkk. (2000). Pembelajaran Kooperatif. Surabaya : Universitas Negeri Surabaya.

Mariana, M.A. (2004). Pembelajaran Remedial. Jakarta: Direktorat Tenaga Pendidikan 
Slameto. (2003). Belajar dan Faktor-Faktor Belajar Ynag Mempengaruhinya. Rineka Cipta : Jakarta

Sugiyono, (2005). Statistik Untuk Penelitian: Bandung : Alfabeta

Sugiyono, (2008). Metode Penelitian Penelitian Pendekatan Kuantitatif dan Kualitatif $R \& B$. Bandung : Alfabeta

Suprijon, Agus. (2009). Cooperatif Learning Teori Dan Aplikasi Paikem. Yogyakarta:Pustaka Belajar. 